\title{
Science Teachers' Views about Inclusion of Socio-Scientific Issues in UAE Science Curriculum and Teaching
}

\author{
Sara Samir El Arbid
}

UAE University, United Arab Emirates, 201470350@иаеи.ac.ae

\section{Hassan H. Tairab}

UAE University, United Arab Emirates, tairab@uaeu.ac.ae

The purpose of this study was to examine the views of secondary school science teachers regarding the inclusion of socio-scientific issues (SSI) in the curriculum, and the factors that may facilitate or impede their inclusion. A survey administered to 130 science teachers of different background and experiences. The findings revealed that science teachers had positive views on the inclusion of SSI in the curriculum. Participants identified resources, teaching strategies, and knowledge as factors that facilitated the inclusion of SSI in the curriculum. Factors that could impede the inclusion of SSI in the curriculum included the need to implement teaching strategies based on actual socio-scientific issues, students' lack of maturity, and cultural influences that might limit participation levels. There were statistically significance differences between the views of science teachers who had prior knowledge of SSI, and the SSI content provided in the professional development programs attended. Science teachers' prior knowledge and professional development programs attended have also affected their views about the factors that facilitate or impede the inclusion of SSI in the curriculum. The findings were discussed in the context of science education research and how science teachers might adapt the science curriculum to effectively incorporate SSI.

Keywords: science curriculum, science teachers' views, socio-scientific issues, UAE

\section{INTRODUCTION}

The ever-growing field of scientific knowledge and on-going technological advances have linked social issues with science to an unprecedented degree. This transformation has precipitated the need to reform school science curricula in such a way that the emerging socio-scientific issues, which are often sensitive and even controversial, are incorporated into the students' science curricula. Socio-scientific issues (SSI) may foster controversies in communities, and have become a concern for science educators. They include matters such as human cloning, genetically manufactured food, environmental 
pollution, and radioactive waste disposal (Lee, Abd-El-Khalick \& Choi, 2006; Ozden, 2015), which are a product of the advancement of science and technology, and have created much confusion and disagreement among community members. It is therefore imperative that SSI are included in the school curricula and taught as early as possible. Their inclusion in the science curricula allows students to develop scientific reasoning abilities, critical thinking skills, moral and ethical reasoning, and bio-ethical decisionmaking skills (Lee, Abd-El-Khalick \& Choi, 2006; Kara, 2012; Gutierez, 2014, Ozden, 2015, Chen \& So, 2017; Chin, Yang \& Tuan, 2015). It also fosters students' understanding of the nature of science (Khishfe, Alshaya, BouJaoude, Mansour \& Alrudiyan, 2017) and scientific literacy (Sadler, 2009), which has become a universal goal of science education.

Including SSI in school curricula is difficult, however, especially in countries with a relatively conservative nature such as Islamic countries, and even among Christian factions in the Western world. In some contexts, science is practiced under the cultural influences of a community's social, economic, political, and religious circles (Kara, 2012). Scientists' perceptions are based on their assumptions, beliefs, values, biases, and training, which influence the kinds of problems they identify, what they observe, and how they understand these problems. Hence, scientists make value judgments (Lederman, Abd-El-Khalick, Bell \& Schwartz, 2002). These issues are necessarily dealt with not only in the scientific knowledge domain, but also depend on students' moral reasoning and judgmental skills. Zeidler \& Sadler (2008) use this argument to further support the inclusion of these issues in science curricula, to give students opportunities to develop these skills in tandem with the development of scientific literacy.

Internationally, a number of research studies have explored the inclusion of SSI and its implementation in science curricula (Lee, Abd-El-Khalick \& Choi, 2006; Sadler, Barab \& Scott, 2007; Sadler, Romine, \& Topçu, 2016; Chin, Yang, \& Tuan, 2016). For example, Lee, Abd-El-Khalick and Choi (2006) found that Korean secondary science teachers perceived a need to address SSI in their classrooms. However, only a few of these teachers were able to implement this teaching or discuss SSI. This is due mainly to the lack of instructional time, the unavailability of relevant resources, and low personal science teaching efficacy (PSTE). Chin, Yang and Tuan (2016), who studied the impacts of introducing SSI into the curriculum in China, found that when sixth grade students in central Taiwan were taught about a global climate change issue using argumentation strategies, they showed significant improvements in writing, the associations they made when reading, and using argument to learn.

A large number of previous research studies focused on students and teachers' conceptions of SSI. A similar focus was also noted on the impact of SSI on cognitive development, reasoning, critical and argumentation skills, as well as on moral and ethical development (Zeidler, Sadler, Applebaum \& Callahun, 2009; Topcu, Sadler \& Yilmaz, 2010; Topcu, Yilmaz \& Sadler, 2011; Eastwood et al., 2012; Dawson \& Venville, 2013; Foong \& Daniel, 2013; Ottander \& Ekborg, 2012; Zeidler et al., 2013). For example, Eastwood et al. (2012) revealed that students who were exposed to SSI tended to use examples to describe their views of the social/cultural nature of science, 
and increasingly communicated in a scientific way. Another critical field of science education research is the contribution of SSI to improving students' abilities to use informal reasoning (Dawson \& Venville, 2013). Berne (2014) and Foong and Daniel (2013) found that when students were introduced to SSI, they progressed significantly in terms of ethical reasoning, argumentation, and aptitudes. Zeidler, Sadler, Applebaum and Callahun (2009) used a reflective judgment model as a tool to explore possible relationships between SSI inclusion and reflective judgment. They found that students had a more sophisticated epistemological stance toward higher stages of reflective judgment. Knowledge of SSI was also found to impact positively on informal reasoning, casual thinking, and social and emotional development among pre-service science teachers (Topcu, Sadler \& Yilmaz, 2010; Topcu, Yilmaz \& Sadler, 2011).

The research conducted to date on the extent to which science teachers use SSI to promote student learning has been inconclusive. However, citing various studies, Karahan (2015) noted that only a small percentage of the teachers incorporate SSI contents into their science classrooms on a regular basis. Karahan (2015) recognizes the fact that despite the vast body of literature that delves into SSI and teaching, along with values and motivations, there is little focus on these teachers' practices and the potential outcomes for their learners. Karahan (2015) pointed out the need for in-depth studies that will also focus on how the SSI-based learning environment is designed and taught. A study is also needed to focus on the beliefs and motivations that support effective SSI teaching, and how students respond to these practices. Sadler (2009) stated that teaching science content alone is not sufficient, if the objective is to help students become better at negotiating scientific challenges, especially with regard to applications of science and technology that could help them become well-rounded citizens.

The United Arab Emirates (UAE) has yet to include controversial topics in its science curriculum in both private and public schools. Official religious views on SSI have yet to be classified in Arab states, and so also the likely impacts of teaching these issues (Dagher \& BouJaoude, 2011). The current failure to include SSI in the science curricula could limit the students' knowledge about issues emerging at the cutting edge of the new technologies that are being developed around the world. In this environment, students may not be given an opportunity to develop their decision-making skills in bioethical issues, or in the development of the argumentation skills that are directly related to these issues.

Although public acceptance/refusal of including SSI in the curriculum does have an indirect impact on teaching, the willingness of science teachers to teach SSI seems to have a direct impact on what and how SSI are introduced into classrooms. Teachers are a primary source of education of students, and their beliefs and views are very important to how students receive the material they are taught. Science teachers often discuss issues related to the inclusion of SSI in the curriculum in professional learning communities such as forums, workshops, and conferences. In schools today, science teachers are expected to incorporate real-life applications when teaching any subject, and specifically when teaching science. However, given the controversial nature of some scientific topics, teachers in this study's context are reluctant to integrate them into the 
science curricula. Although many studies conducted in the international context have assessed the views and implementation of SSI by teachers (Sadler, Barab \& Scott, 2007; Ozden, 2015), teachers are still not comfortable with the task of implementing SSIrelated teaching strategies (Duschl, 2007; Lee, Abd-El-Khalick \& Choi, 2006). For example, Lee, Abd-El-Khalick and Choi (2006) found that teachers perceived that a lack of instructional time and the unavailability of relevant resources were the primary obstacles constraining the implementation of SSI teachings in Korea. Mirroring these findings, it was found that educators' personal views would determine whether SSI would be included in the curriculum and taught in the classroom (Berkman, Pachecho \& Plutzer, 2008). This may clearly suggest that the effective implementation of educational reform lies primarily at the hand of teachers. When teachers' personal beliefs and values synchronize well with the SSI perspectives, they are more likely to promote SSI based teaching strategies and extend discussion of SSI beyond the boundaries of the curriculum.

\section{Socio-Scientific Issues and UAE Science Curricula}

The United Arab Emirates, throughout the years, has tried to develop and maintain a world-class quality education for its citizens. Aside from investing heavily in the country's educational system, the UAE government also sends students abroad to provide them with a leading-edge world-class education that could be useful in the UAE's futuristic vision. In light of its educational reforms, it is imperative that socioscientific issues are integrated into the country's educational curriculum. The UAE has also introduced twenty-first century competencies and skills. The UAE framework, which is based on the country's Abu Dhabi Economic Vision 2030, emphasizes the importance of providing students with problem-solving and critical-thinking skills, as well as global and environmental awareness. It targets enhancing the skills of all students. A strategy for incorporating SSI into the curriculum may help enhance these skills. For example, in the UAE context, genetically modified fruits and vegetables are currently being sold in grocery shops. Students need to understand why these choices are being made, and how they are impacting the society and the economy. The knowledge that students will acquire from this learning, will eventually prepare them to fully engage in the real world, and particularly their future workplaces.

Given the UAE's cultural orientation, the inclusion of SSI in the secondary school science curriculum remains controversial, especially with regard to science teachers' views about SSI. Although there are numerous science education research findings related to the UAE context-such as student-centered and inquiry-based learning (Dickson, Kadbey \& McMinn, 2015, Al Naqbi, 2010) - there are still no studies in the UAE that document teachers' views on the inclusion of SSI in the curriculum. In countries like Turkey, teachers were amenable to the inclusion of SSI (Kara, 2012); however, effective measures are still needed to overcome some residual issues.

Several different scenarios might be used in the process of incorporating SSI in the UAE's science curriculum. First, the educational system in the country is volatile in terms of students and teachers' backgrounds. This volatility encompasses diversified cultural, religious, and racial views of SSI. This may have impact on the norms of UAE 
students with regard to how their society may view some sensitive aspects of SSI. For example, a teacher who comes from a foreign country could have a different view of certain SSI-related curriculum topics, which might contradict how the student views the subject. This could stir up conflicting opinions and beliefs on the topic. Cultural differences present the most significant barrier likely to impact the possible adaption of SSI in UAE school curricula. From a different angle, previous research studies suggested that some science teachers are inclined to engage in debatable SSI issues (Gayford, 2002) and "prefer to maintain being harmonious with scientific knowledge and inquiry-based curriculum of their subject matter" (Hyunju \& Klaus, 2009, p. 934). In a recent UAE context related study, participants showed poor awareness of biotechnology related issues (AbuQamar, Alshannag, Sartawi, \& Iratni, 2015), suggesting that awareness is crucial to understanding of the role of biotechnology in human societies. The poor awareness of students of SSI related issues may be attributed to ineffective approaches to teaching SSI as described by Gayford (2002) and Hyuniu and Klaus (2009). Furthermore, given present circumstances, a sizeable percentage of science teachers that come from different cultural backgrounds could also pose problems with regard to constructive pedagogical discussions of SSI.

Given the scarcity of research and views on SSI, and the failure to address the inclusion of SSI particularly in the UAE context, this study aims to examine science teachers' views on the inclusion of SSI in the science curriculum in UAE schools. Specifically, the study intends to document science teachers' views on the inclusion of SSI in the curriculum, and identify the factors that are likely to facilitate or impede such inclusion, by asking the following questions:

1. What are the science teachers' views on the inclusion of SSI in the science curriculum?

2. What factors are more likely to facilitate or impede the inclusion of SSI in the secondary science curriculum?

3. What are the impacts of science teachers' demographic variables-including gender, teaching experience, and background knowledge - as measured by prior knowledge of SSI and professional development training, on their views of SSI, and the factors that are more likely to facilitate or impede their inclusion in secondary science curricula?

We believe that the inclusion of SSI in the science curriculum will afford students the opportunity to develop discourse and argumentation skills that emphasize the development of competence in decision making, ethical reasoning, and critical thinking. Hence, it is important that students within the UAE are subjected to SSI to increase their scientific literacy, and develop their critical thinking and bioethical decision-making skills. In addition, we also believe that the views of science teachers on SSI will be beneficial to science teachers themselves, and those who develop curricula, to strategically plan for more effective classroom activities, future teacher training activities, and professional development training programs. 


\section{METHOD}

\section{Context of the Study}

This study was conducted in UAE secondary schools at a time when significant educational reforms were underway in the country. Since 2006, various educational reforms have significantly improved the UAE's educational system (Dickson, Kadbey and McMinn, 2015). This enormous transformation has been credited to the government's considerable investment in the educational system for its ever-expanding population. In the country's 2021 vision, education remains at the top of the government's priorities, and is seen as the major factor for enhancing its human capital, and preparing its people for a more diversified knowledge-based economy. Among the recent reforms introduced is Education 2020, an ambitious five-year plan that aims to deliver quality improvements in the country's educational system, giving more emphasis to how teachers teach, and how students acquire the intended learning outcomes. Within this framework, the UAE has embraced the concept of teaching socio-scientific issues early in secondary education, while realizing that the inclusion of socio-scientific issues in the curricula will provide students with an opportunity to become more aware of the perspectives of SSI.

\section{Design}

This study is based on an exploratory descriptive survey design, which determines and describes a situation, and compares how groups or sub-groups view a certain issue (Gay, Mills and Airasian, 2011). The purpose of this study is to describe the current status of SSI inclusion in the UAE science curriculum from the science teachers' perspective. This design, therefore, allows us to assess the views of science teachers as a first step to understanding how SSI are included and taught in the UAE science curriculum.

\section{Participants}

The sample used for this study included 131 participants drawn randomly from a population of secondary school science teachers: $34 \%$ were male and $66 \%$ were female, $22 \%$ of the participants had less than 5 years' teaching experience, compared with $78 \%$ who had more than 5 years' teaching experience. Furthermore, 56\% of the participants had taken courses related to SSI during their teacher preparation programs, while $49 \%$ of them had attended professional development training in the last 3 years of their professional life. These background characteristics were assessed for their impacts on the science teachers' views on SSI, as they were found in previous research findings to have differential impacts on the knowledge and understanding of SSI (Ozden, 2015).

Prior to data collection, the purpose of the study was explained to the participating teachers and their consent was secured via personal contact with each participant. Furthermore, the questionnaire included a statement as part of the instruction to participants, to inform them that their participation in the study was on voluntary basis and that participants may suspend their participation any time they feel. 


\section{Instrument}

A survey instrument consisting of 24 statements was developed using previous studies of science teachers' views on SSI such as those of Kara (2012), Lee, Abd-El-Khalick and Choi (2006), and Ozden (2015). Likert-type statements asked science teachers to clarify their views on SSI, and the factors that are more likely to facilitate or impede their inclusion in the science curriculum. The survey instrument addressed two SSIrelated domains, namely science teachers' overall views of the necessity for including SSI in the science curriculum (10 statements), and their views on the factors that are more likely to facilitate or impede the inclusion of SSI in the curriculum (14 statements). In addition, the survey instrument gathered information on background characteristics such as gender, teaching experience, prior knowledge of SSI, and attendance at professional development training related to SSI. The statements in the survey instrument were first was written in English, as the intended targets were both Arabicand English-speaking science teachers. They were then translated into Arabic, and then retranslated into English, to check the validity of the translation.

To establish the instrument's content and construct validity, a panel that included three science education professors and three science teachers reviewed the survey instrument and provided comprehensive feedback, with regard to the extent of coverage proposed for the intended domains of SSI, and the suitability and appropriateness of the survey for its intended purpose. Based on this panel review, changes were made to the final draft of the survey that included switching the order of items to prioritize them and reword four statements.

The final 24 statements were piloted using 40 science teachers from similar schools that were not participating in the study. The overall Cronbach's alpha was calculated to be 0.80 , for science teachers' general views of the SSI domain (Statement 1 to 10), it was found to be 0.73 . For science teachers' views of facilitating factors (Questions 11 to 14 and Questions 23 and 24), the reliability was found to be 0.81 , whereas for science teachers' views of impeding factors (Questions 15 to 22) Cronbach's alpha was calculated as 0.66. Taken together, these indices of reliability were regarded as reflecting a level of internal consistency appropriate to the purpose of this study.

\section{Data Analysis}

Descriptive statistics using frequencies, percentages, and mean scores were employed to analyze the data collected by the survey. Inferential statistics (t-test) were used to provide answers to research questions about the statistically significant differences, if any, between science teachers' views of the inclusion of SSI in the curriculum. The analyses also includes statistically significant differences related to factors that may facilitate or impede the inclusion of SSI in the secondary science curriculum, and the impacts of science teachers' demographic variables (gender, teaching experience, and background knowledge as measured by prior knowledge of SSI and professional development training) on their views of SSI. 


\section{FINDINGS}

Science teachers' views regarding the inclusion of SSI in the science curriculum, and factors that may facilitate or impede its inclusion in the curriculum, are presented in Tables 1 to 3 below. Participants' responses to each statement in the survey and their rank order from highest to lowest are also presented.

\section{Science teachers' views regarding the inclusion of SSI in the science curricula}

Table 1 shows that a high percentage of participants either strongly agreed or agreed with the inclusion of SSI, because students need to enhance their abilities to decide their own positions $(M=4.46)$, to increase student interest in SSI issues $(M=4.30)$, and, to increase their level of interest in socio-scientific issues related to science and technology $(\mathrm{M}=4.28)$. On the other hand, a higher percentage of disagreement was evident with regard to the statement that suggested the inclusion of SSI in other curricula (SSI are more appropriately dealt with in ethics, religion, or social studies classes than in science class). Only $21.4 \%$ of the participants strongly agreed or agreed with this statement.

Table 1

Science Teachers' Attitudes toward the Inclusion of SSI in the Curriculum

\begin{tabular}{|c|c|c|c|c|}
\hline Statement & Rank & $\begin{array}{l}\text { Strongly } \\
\text { Agree / Agree }\end{array}$ & M & SD \\
\hline $\begin{array}{l}\text { I want to develop teaching and learning materials on socio- } \\
\text { scientific issues for my class }\end{array}$ & 5 & $98.50 \%$ & 4.14 & 0.39 \\
\hline $\begin{array}{l}\text { If I can get materials on socio-scientific issues, I am willing to use } \\
\text { them in the class }\end{array}$ & 4 & $92.30 \%$ & 4.15 & 0.53 \\
\hline $\begin{array}{l}\text { I am willing to participate in a program that helps teachers deal } \\
\text { with socio-scientific issues }\end{array}$ & 6 & $87.80 \%$ & 3.95 & 0.73 \\
\hline Introducing socio-scientific issues into science class is necessary & 3 & $93.10 \%$ & 4.28 & 0.60 \\
\hline $\begin{array}{l}\text { I think that it is more appropriate to deal with socio-scientific issues } \\
\text { in ethics and religion, and social studies classes than in science } \\
\text { class }\end{array}$ & 9 & $21.40 \%$ & 2.79 & 0.89 \\
\hline $\begin{array}{l}\text { Introducing socio-scientific issues into science classes will increase } \\
\text { students interest in these issues }\end{array}$ & 2 & $94.70 \%$ & 4.30 & 0.57 \\
\hline $\begin{array}{l}\text { Students need to be concerned with socio-scientific issues related to } \\
\text { science and technology }\end{array}$ & 3 & $96.20 \%$ & 4.28 & 0.53 \\
\hline $\begin{array}{l}\text { Students need to learn and enhance their ability to decide their own } \\
\text { positions about socio-scientific issues in science class }\end{array}$ & 1 & $95.40 \%$ & 4.46 & 0.58 \\
\hline $\begin{array}{l}\text { Socio-scientific issues should be a compulsory part of the science } \\
\text { curriculum }\end{array}$ & 8 & $59.60 \%$ & 3.46 & 0.90 \\
\hline
\end{tabular}

\section{Science teachers' views on the factors that facilitate inclusion}

Table 2 summarizes the views of science teachers regarding the factors that facilitate the inclusion of SSI in the curriculum. Factors related to the knowledge of instructional strategies seem to be the driving force behind science teachers' confidence in the inclusion of SSI. They all strongly agree or agree that these factors are facilitating factors, as reflected in the high mean scores shown in Table 2. As shown in Table 2, science teachers seem to have confidence that their teaching strategies allow them to teach SSI in the classrooms $(M=3.82)$, that the necessary assessment methods may be used to assess SSI learning $(M=3.73)$, that they have the knowledge and understanding 
needed to teach SSI effectively $(\mathrm{M}=3.69)$, and that they have a general knowledge and understanding of SSI $(M=3.59)$. Overall, the percentages of science teachers strongly agreeing or agreeing with these factors ranged between $58 \%$ and $82.4 \%$.

Table 2

Science Teachers' Views on the Factors that Facilitate the Inclusion of SSI

\begin{tabular}{|c|c|c|c|c|}
\hline \multirow[b]{2}{*}{ Statement } & \multicolumn{3}{|c|}{ Strongly Agree } & \multirow[b]{2}{*}{ SD } \\
\hline & Rank & / Agree & M & \\
\hline $\begin{array}{l}\text { I have the teaching strategies that allow me to deal with socio- } \\
\text { scientific issues in science classes }\end{array}$ & 1 & $79.40 \%$ & 3.82 & 0.44 \\
\hline I have a full understanding of what socio-scientific issues are & 4 & $59.60 \%$ & 3.59 & 0.66 \\
\hline $\begin{array}{l}\text { I have enough resources to develop teaching and learning materials } \\
\text { about socio-scientific issues }\end{array}$ & 6 & $82.40 \%$ & 3.22 & 0.73 \\
\hline $\begin{array}{l}\text { I have the knowledge necessary to effectively teach about socio- } \\
\text { scientific issues to my secondary school students }\end{array}$ & 3 & $67.20 \%$ & 3.69 & 0.61 \\
\hline $\begin{array}{l}\text { I am confident in using assessment strategies to assess socio- } \\
\text { scientific issues }\end{array}$ & 2 & $69.50 \%$ & 3.73 & 0.65 \\
\hline $\begin{array}{l}\text { I have knowledge about different instructional methodologies for } \\
\text { effective application of socio-scientific issues in the classroom }\end{array}$ & 5 & $58.00 \%$ & 3.57 & 1.05 \\
\hline
\end{tabular}

\section{Science teachers' views on the factors that impede inclusion}

Table 3 summarizes the views of the science teachers with regard to the factors that impede the inclusion of socio-scientific issues (SSI) in the curriculum. The highest means reported were related to student factors that are related to their ability and readiness to contextualize SSI in a real classroom $(M=3.60)$, their maturity $(M=3.39)$, and their language abilities $(\mathrm{M}=3.21)$.

Table 3

Teachers' Views of the Factors that Impede Inclusion in the Curriculum

\begin{tabular}{|c|c|c|c|c|}
\hline Statement & Rank & $\begin{array}{l}\text { Strongly } \\
\text { Agree/ Agree }\end{array}$ & M & SD \\
\hline $\begin{array}{l}\text { I do not have enough class time to deal with socio-scientific } \\
\text { issues }\end{array}$ & 8 & $13.00 \%$ & 2.63 & 0.79 \\
\hline $\begin{array}{l}\text { I believe that students are not mature enough to be interested in } \\
\text { and understand socio-scientific issues }\end{array}$ & 2 & $47.30 \%$ & 3.39 & 0.91 \\
\hline $\begin{array}{l}\text { I believe that students' language ability limits their ability to } \\
\text { understand socio-scientific issues }\end{array}$ & 3 & $39.70 \%$ & 3.21 & 0.95 \\
\hline $\begin{array}{l}\text { Classes dealing with socio-scientific issues are most likely to be } \\
\text { classes for high achieving students }\end{array}$ & 4 & $36.60 \%$ & 2.92 & 1.05 \\
\hline $\begin{array}{l}\text { I believe that science classes addressing socio-scientific issues } \\
\text { have little influence on the achievement of students with low } \\
\text { motivation }\end{array}$ & 7 & $22.90 \%$ & 2.68 & 0.93 \\
\hline $\begin{array}{l}\text { Addressing socio-scientific issues in science classes could } \\
\text { confuse students about their own religious values }\end{array}$ & 6 & $30.50 \%$ & 2.72 & 1.01 \\
\hline $\begin{array}{l}\text { I believe that science classes addressing socio-scientific issues } \\
\text { have little influence on the achievements of students with low } \\
\text { participation level }\end{array}$ & 5 & $38.20 \%$ & 2.88 & 1.01 \\
\hline $\begin{array}{l}\text { Dealing with socio-scientific issues using various teaching } \\
\text { strategies is not possible in a "real" classroom situation }\end{array}$ & 1 & $64.10 \%$ & 3.60 & 0.93 \\
\hline
\end{tabular}


On the other hand, science teachers viewed factors such as those related to resources and instructional time as having a low impact on their views as judged by the magnitude of the mean scores. Science teachers expressed the view that they do not have enough time to deal with SSI $(M=2.63)$, that SSI as having limited influence on raising the achievements of students with low motivation $(\mathrm{M}=2.68)$, and that $\mathrm{SSI}$ as influencing students' religious values. The overall percentages of science teachers strongly agreeing or agreeing with these factors ranged between $13 \%$ and $64.10 \%$.

The impacts of teachers' demographic variables (gender, teaching experience, and prior knowledge) on their views on inclusion

Within the demographic variables there were no statistically significant differences between males and females, or experienced and novice participants, thus confirming that teachers' views are similar with regard to the inclusion of SSI in the curriculum. However, among those with prior knowledge of SSI as assessed by their having attended SSI courses at the undergraduate level, there was a statistically significant difference between the two groups $(t=3.05, p \leq 0.03)$. There was also a statistically significant difference between the views of participants based on their attendance at SSI-related professional development training $(t=5.91, \mathrm{p} \leq 0.00)$. Prior knowledge of SSI and professional development training for SSI seem to positively impact science teachers' views about the inclusion of SSI in the curriculum.

The impacts of teachers' demographic variables on their views about factors that facilitate the inclusion of SSI in the curriculum

There were no statistically significant differences attributed to gender, or participants' teaching experience. However, with regard to prior knowledge of SSI, as assessed by having attended SSI courses at the undergraduate level, there was a statistically significant difference between the two groups $(\mathrm{t}=2.33, \mathrm{p} \leq 0.02)$. There was also a statistically significant difference between the participants based on their attendance at professional development training for SSI $(t=3.24, \mathrm{p} \leq 0.00)$.

The impacts of science teachers' demographic variables on their views regarding the factors that impede the inclusion of SSI in the curriculum

The variables of gender, prior knowledge of SSI, and professional development training had no impact on the views of participants, as there were no statistically significant differences between participants' responses based on these variables. On the other hand, a statistically significant difference was detected with regard to teaching experience, in favor of less-experienced science teachers $(t=2.40, p \leq 0.02)$.

\section{DISCUSSION}

The results presented in this study show that science teachers have strong positive views on the inclusion of SSI in the secondary school science curriculum. They feel that the inclusion of SSI would provide students with the opportunity to enhance their abilities to evaluate socio-scientific issues for themselves, to increase their interest in SSI issues, and, to increase their interest in socio-scientific issues related to science and technology. Furthermore, science teachers had strong opposing views on the inclusion of SSI as part 
of an ethical, religious, or social studies curriculum. They felt that it was less appropriate to deal with SSI in ethics, religion, or social studies classes than in science. This could be due to the deeply-rooted beliefs of science teachers that science classes would provide a systematic study of these issues, while in religion/ethics classes these issues might be viewed from religious/ethical perspectives that may not achieve the stated goals of scientific literacy. In religion/ethics classes, teachers' personal beliefs about these issues might also be transferred to students (as a given), instead of providing students with an opportunity to form their own opinions and arguments. Furthermore, findings of recent research studies also suggest that we should not only focus on ethical and moral dimensions of SSI but also expand classroom discussion to enhance student argumentation and decision making abilities (Nam and Chen, 2017). Recent studies in a similar context (Mansour, 2008; Khishfe, 2014; Khishfe, Alshaya, BouJaoude, Mansour and Alrudiyan, 2017) have suggested that cultural factors such as religious beliefs can significantly influence views and beliefs about SSI.

These results support previous research findings such as those of Lee, Abd-El-Khalick and Choi (2006), with regard to the Korean context, and Kara (2012), in a Turkish context. Dawson and Venville (2013) found that when students were subjected to SSI their argumentation and informal reasoning skills improved significantly-which indicated the importance of SSI in maximizing student learning at both conceptual and procedural levels. Hence, including curricular options for students that include SSI topics may expand their skills. This is especially important in current times where it is essential that students use their reasoning skills in real-life situations. Additionally, it is important that they have the skills to differentiate social and scientific topics and reflect on their importance and debate them with others.

On the other hand, science teachers regarded their professional backgrounds as key to the successful inclusion of SSI in the science curriculum. They had a high regard for content knowledge and the pedagogy that will be used to implement the teaching strategies and assessment methods as factors that might lead to the successful inclusion of SSI in the curriculum. Nevertheless, despite having a high level of confidence in their abilities to handle SSI, teachers still have some concerns with regard to finding resources to teach SSI. Unlike Lee, Abd-El-Khalick and Choi (2006), who found that teachers had a low personal science teaching efficacy (PSTE) that was reflected in their content and pedagogical knowledge and strategies to address these issues, teachers in the present study have a relatively high personal science teaching efficacy (PSTE) compared to those reported by Lee, Abd-El-Khalick and Choi (2006). However, the results in this study support those reported by Kara (2012), who found that pre-service science teachers perceived themselves as having the content knowledge and pedagogical expertise needed to teach SSI in secondary-school science classrooms. They also expressed confidence in their abilities to develop the resources needed to teach SSI. This contrasts with the current study's findings. These results enunciate the need for professional development that transforms teachers' practices in SSI's. Teachers need a thorough explanation of what SSI's are, how to present them in the classroom and how to assess them. 
When asked about student-related factors, science teachers indicated that students' abilities and readiness to contextualize SSI in an actual classroom, their maturity, and their language abilities are factors that may interfere with the inclusion of SSI in the curriculum. Previous studies have suggested that internal student factors - such as ability and readiness - may interfere with the understanding of SSI (Khishfe, Alshaya, BouJaoude, Mansour and Alrudiyan, 2017, Walker and Ziedler, 2007). SSI learning depends on intellectual and argumentation skills. If students do not have the readiness, the language level, and/or ability to reason and develop the argumentation skills needed to make decisions and justify these decisions, they will not achieve the stated goals of including SSI in the curriculum. In the context of this study, students are taught science in the English language, which is not their first language, and hence, they may face some problems comprehending these SSI due to their limited command of the language of instruction.

On the other hand, science teachers viewed teaching and learning resources and instructional time as having a low impact on the inclusion of SSI in the science curriculum. In the present study, these views are consistent with current reforms that have already been introduced into the schools, which have prioritized ready access to resources and school infrastructure, since all schools are reasonably well-resourced in terms of teaching and learning resources, as well as human resources.

This study also explored the relationships between the variables of gender, teaching experience, prior knowledge of SSI, professional development activities attended, and participants' views on the inclusion of SSI in the science curriculum. The results did not show any statistically significant differences among participants based on gender and teaching experience, thus indicating that science teachers' views are similar with regard to the inclusion of SSI in the curriculum. However, the variables of prior knowledge of SSI - as demonstrated by SSI courses studied at the undergraduate level - and professional development activities - as measured by the professional development training attended-showed statistically significant differences between the participants based on these groups. It can be seen that science teachers who have been subjected to both SSI courses and professional development training have more positive views of SSI, since they might know more about the importance of including such topics in the curriculum, and hence have developed a high regard for SSI. These results are similar to those of Nam and Chen (2017), who found that subjecting pre-service science teachers to discussions of environmental SSI not only affected the pre-service science teachers' negotiating patterns during a scientific inquiry class, but also enhanced their epistemic understanding of content. In another study, Kara (2012) found that there were no statistically significant differences in participants' perceptions according to gender. In the same study, the teachers were involved in professional development activities that appeared to promote their perceptions of personal teaching efficacy, and how their values might impede the inclusion of SSI in the curriculum, thus emphasizing the importance of teachers' professional development or knowledge of SSI from courses taken at the undergraduate level. SSI are multi-disciplinary in nature, and so it is important from this perspective that teachers have knowledge of the subject matter and related economic, political, and social issues. 


\section{IMPLICATIONS}

The findings reported in this study showed that SSI is an important issue in the science curriculum, as indicated by the views expressed by the participating science teachers. This study's findings may also contribute to further explorations of the interactions of teachers with the science curriculum, especially with regard to their views on adapting the curriculum to better suit the needs of today's students. The findings reported in this study may serve as a precursor to larger studies that aim to better understand the views of teachers with regard to including SSI in the curriculum. The study clearly showed that the science teachers who had previously acquired knowledge of SSI might have a better chance of including them in their teaching, as they have demonstrated positive views with regard to their inclusion in the curriculum, and this finding suggests scope for further research. Prior knowledge of SSI allows science teachers to be more aware of the links between improving students' scientific literacy, promoting their argumentation skills, and enhancing their decision-making skills.

This study's findings point to the value of professional development for teachers on the subject of SSI. Professional development activities will help teachers learn how to address SSI topics in the curriculum, and greatly enrich science teachers' understanding of SSI. However, as suggested by Aikenhead (2007) professional development activities may not assist teacher to develop sound and coherent perspectives about SSI. This is because teachers tend to be constrained by their belief systems, values, and their own ideologies, particularly in the context of the current study. The tension between personal beliefs, values and ideologies on the one hand and the need to implement advocated reform may challenge teachers' ability to implement effective SSI curriculum. It is therefore, we call for adopting new perspectives to approach science teachers' professional development programs. The aim is to challenge science teachers' deeprooted ethical/religious beliefs and moral values that encourage science teachers to acquire knowledge and understanding about SSI. Science teachers' views on the incorporation of SSI may change, based on their increased knowledge of SSI, and how this content can be taught. Doing so would also allow science teachers to gain insights into more powerful teaching strategies based on real SSI, and thereby improve their chances of addressing SSI in their classrooms.

\section{REFERENCES}

AbuQamar, S., Alshannag, Q., Sartawi, A., \& Iratni, R. (2015). Educational awareness of biotechnology issues among undergraduate students at the United Arab Emirates University. Biochemistry and Molecular Biology Education, 43(4), 283 - 293.

Aikenhead, G.S. (2007). Humanistic perspectives in the science curriculum. In S. Abell \& N. Lederman (Eds.), Handbook of research on science education (pp.1-6). Mahwah, NJ: Lawrence Erlbaum Associates.

Berne, B. (2014). Progression in ethical reasoning when addressing socio-scientific issues in biotechnology. International Journal of Science Education, 36(17), 29582977. 
Berkman, M. B., Pacheco, J. S., \& Plutzer, E. (2008). Evolution and creationism in America's classrooms: A national portrait. PLoS Biology, 6(5), 920924. https://doi.org/10.1371/journal.pbio.0060124.

Chen, Y., \& So, Winnie. (2017). An investigation of mainland China high school biology teachers' attitudes toward and ethical reasoning of three controversial bioethics issues. Asia-Pacific Science Education, 3, 1. doi: 10.1186/s41029-016-0012-6.

Chin, C. C., Yang, W. C., \& Tuan, H. L. (2016). Argumentation in a socio-scientific context and its influence on fundamental and derived science literacies. International Journal of Science and Mathematics Education, 14(4), 603-617.

Dagher, Z. R., \& BouJaoude, S. (2011). Science education in Arab states: Bright future or status quo? Studies in Science Education, 47(1), 73-101.

Dawson, V., \& Venville, G. (2013). Introducing high school biology students to argumentation about socio-scientific issues. Canadian Journal of Science, Mathematics and Technology Education, 13(4), 356-372. doi: 10.1080/14926156.2013.845322.

Dickson, M., Kadbey, H., \& McMinn, M. (2015). Comparing reported classroom practice in public and private schools in the United Arab Emirates. Procedia Social and Behavioral Sciences 186, 209 - 215. doi: 10.1016/j.sbspro.2015.04.079.

Duschl, R. A. (2007). Quality argumentation and epistemic criteria. In S. Erduran \& M. P. Jiménez-Aleixandre (Eds.), Argumentation in science education (pp. 159-175). Netherlands: Springer.

Eastwood, J. L., Sadler, T. D., Zeidler, D. L., Lewis, A., Amiri, L., \& Applebaum, S. (2012). Contextualizing nature of science instruction in socio-scientific issues. International Journal of Science Education, 34(15), 2289-2315. doi: 10.1080/09500693.2012.667582.

Foong, C.-C., \& Daniel, E. G. S. (2013). Students' argumentation skills across two socio-scientific issues in a Confucian classroom: Is transfer possible? International Journal of Science Education, 35(14), 2331-2355. doi: 10.1080/09500693.2012.697209.

Gay, L. R., Mills, G. E., \& Airasian, P. W. (2011). Educational research: Competencies for analysis and applications. Pearson.

Gutierez, S. B. (2014). Integrating socio-scientific issues to enhance the bioethical decision-making skills of high school students. Int. Education Studies, 8(1), 142.

Hyunju, L., \& Klaus, W. (2009) Science teachers' inspiration for teaching socio-scientific issues: Disconnection with reform efforts, International Journal of Science Education, 31(7), 931-960. doi: 10.1080/09500690801898903.

Kara, Y. (2012). Pre-service biology teachers' perceptions on the instruction of socioscientific issues in the curriculum. European Journal of Teacher Education, 35(1), 111129. doi: 10.1080/02619768.2011.633999. 
Karahan, E. (2015). Case studies of secondary school teachers designing socio-scientific issues-based instruction and their students' socio-scientific reasoning. The University of Minnesota. Retrieved from https://conservancy.umn.edu/handle/11299/174863.

Khishfe, R. (2014). Explicit nature of science and argumentation instruction in the context of socio-scientific issues: An effect on student learning and transfer. International Journal of Science Education, 36(6), 974-1016. doi: 10.1080/09500693.2013.832004.

Khishfe, R., Alshaya, F. S., BouJaoude, S., Mansour, N., \& Alrudiyan, K. I. (2017). Students' understandings of nature of science and their arguments in the context of four socio-scientific issues. International Journal of Science Education, 39(3), 299-334.

Lederman, N. G., Abd-El-Khalick, F., Bell, R. L., \& Schwartz, R. S. (2002). Views of nature of science questionnaire: toward valid and meaningful assessment of learners' conceptions of nature of science. Journal of Research in Science Teaching, 39(6), 497521.

Lee, H., Abd-El-Khalick, F., \& Choi, K. (2006) Korean science teachers' perceptions of the introduction of socio-scientific issues into the science curriculum. Canadian Journal of Science, Mathematics and Technology Education, 6(2), 97-117. doi: 10.1080/14926150609556691.

Mansour, N. (2008). The experiences and personal religious beliefs of Egyptian science teachers as a framework for understanding the shaping and reshaping of their beliefs and practices about science-technology-society (STS). International Journal of Science Education, 30(12), 1605-1634. doi:10.1080/09500690701463303.

Nam, Y. \& Chen, Y. (2017). Promoting argumentative practice in socio-scientific issues through a science inquiry activity. EURASIA Journal of Mathematics Science and Technology Education, 13(7), 3431-3461.

Ottander, C. \& Ekborg, M. (2012). Students' experience of working with socioscientific issues: A quantitative study in secondary school. Journal of Research in Science Teaching, 39(10), 1016-1031.

Özden, M. (2015). Prospective elementary school teachers' views about socio-scientific Issues: A concurrent parallel design study. International Electronic Journal of Elementary Education, 7(3), 333.

Sadler, T. D., (2009). Promoting effective science teacher education and science teaching: A framework for teacher decision-making. International Journal of Science Education, 7(4), 821-847.

Sadler, T. D., Barab, S. A., \& Scott, B. (2007). What do students gain by engaging in socio-scientific inquiry? Research in Science Education, 37(4), 371-391.

Sadler, T. D., Romine, W. L., \& Topçu, M. S. (2016). Learning science content through socio-scientific issues-based instruction: A multi-level assessment study. International Journal of Science Education, 38(10), 1622-1635. 
Sadler, T. D., \& Zeidler, D. L. (2005b). The significance of content knowledge for informal reasoning regarding socio-scientific issues: Applying genetics knowledge to genetic engineering issues. Journal of Research in Science Teaching, 37(5), 426- 440.

Topcu, M. S., Sadler, T. D., \& Yilmaz-Tuzun, O. (2010). Pre-service science teachers' informal reasoning about socio-scientific issues: The influence of issue context. International Journal of Science Education, 32(18), 2475-2495. doi: $10.1080 / 09500690903524779$.

Topcu, M. S., Yilmaz-Tuzun, O., \& Sadler, T. D. (2011). Turkish pre-service science teachers' informal reasoning regarding socio-scientific issues and the factors influencing their informal reasoning. Journal of Science Teacher Education, 22(4), 313-332. doi: 10.1007/s10972-010-9221-0.

Walker, K. A., \& Zeidler, D. L. (2007). Promoting discourse about socio-scientific issues through scaffolded inquiry. International Journal of Science Education, 29, $1387-1410$.

Zeidler, D. L., \& Sadler, T. D. (2008). Social and ethical issues in science education: A prelude to action. Science \& Education, 17(8), 799-803.

Zeidler, D. L., Sadler, T. D., Applebaum, S., \& Callahan, B. E. (2009). Advancing reflective judgment through socioscientific issues. Journal of Research in Science Teaching, 46(1), 74-101. doi: 10.1002/tea.20281.

Zeidler, D., Herman, B. C., Ruzek, M., Linder, A., \& Lin, S.S. (2013). Cross-cultural epistemological orientations to socio-scientific issues. Journal of Research in Science Teaching, 50(3), 251-283. doi: 10.1002/tea.21077. 